PACS: $87.14 . \mathrm{C}++\mathrm{c}$, 87.16.Dg

\title{
SPECTRAL BEHAVIOR OF INDICATOR DYES IN THE MODEL PROTEIN - LIPID SYSTEMS
}

\author{
V. Trusova, G. Gorbenko, U. Tarabara, K. Vus, O. Ryzhova \\ Department of Nuclear and Medical Physics, V.N. Karazin Kharkiv National University \\ 4 Svobody Sq., Kharkiv, 61022, Ukraine \\ e-mail: valerija.trusova@karazin.ua \\ Received 27 September, 2017
}

\begin{abstract}
The protolytic and partition equilibria of the indicator dyes in the model lipid and protein-lipid systems have been analyzed. A methodological approach has been developed allowing the partition coefficients of the protonated and deprotonated dye forms to be derived from the spectrophotometric measurements. The partitioning of the indicator dye bromothymol blue into the model bilayer membranes composed of phosphatidylcholine and cardiolipin $(9: 1, \mathrm{~mol}: \mathrm{mol})$ has been examined. The partition coefficient of the protonated dye species into a lipid phase has been found to be 5 orders of magnitude higher than that of the deprotonated dye form. This effect has been interpreted in terms of the differences in the charge distribution over the protonated and deprotonated dye ions, preventing the hydrophobic dye-lipid interactions in the latter case. The reduction of the bromothymol blue partitioning into lipid bilayer in the presence of hemoglobin has been attributed to the protein-induced changes in the structure and physicochemical characteristics of the interfacial membrane region. In the practical aspect, the obtained findings may prove of significance in the design of hemosome-based blood substitutes and elucidating the role of hemoglobin in the molecular etiology of the amyloid disorders, particularly, Alzheimer's disease.
\end{abstract}

KEYWORDS: indicator dye; partition coefficient; liposomes; hemoglobin; protein-lipid interaction

\section{СПЕКТРАЛЬНА ПОВЕДІНКА ІНДИКАТОРНИХ БАРВНИКІВ В МОДЕЛЬНИХ БІЛОК-ЛІПІДНИХ СИСТЕМАХ}

В. Трусова, Г. Горбенко, У. Тарабара, Е. Вус, О. Рижова

Кафедра ядерної та медичної фізики, Харківський національний університет імені В.Н. Каразіна м. Свободи 4, Харків, 61022, Україна

Проаналізовані протолітичні та термодинамічні рівноваги індикаторних барвників в модельних ліпідних та білок-ліпідних системах. Запропоновано методологічний підхід, що дозволяе визначати коефіцієнти розподілу протонованої та депротонованої форм барвника на основі спектрофотометричних вимірювань. Проведено дослідження розподілу індикаторного барвника бромтимолового синього в модельні бішарові мембрани, що складались із фосфатидилхоліну та кардіоліпіну (9:1, моль:моль). Показано, що коефіцієнт розподілу протонованої форми барвника в ліпідну фазу на 5 порядків вище, ніж коефіцієнт розподілу депротонованої форми. Цей ефект був інтерпретований в рамках уявлень про різний розподіл заряду в іонах барвника, що перешкоджає гідрофобним взаємодіям депротонованої форми 3 ліпідами. Спостережуване зменшення розподілу бромтимолового синього в ліпідний бішар у присутності гемоглобіну було пояснено білок-індукованими змінами структури та фізико-хімічних властивостей границі розділу ліпід-вода. У практичному аспекті, отримані результати мають значення для розробки замінників крові на основі гемосом та з'ясування ролі гемоглобіну у розвитку амілоїдних патологій, зокрема, хвороби Альцгеймера.

КЛЮЧОВІ СЛОВА: індикаторний барвник, коефіцієнт розподілу, ліпосоми, гемоглобін, білок-ліпідні взаємодії

\section{СПЕКТРАЛЬНОЕ ПОВЕДЕНИЕ ИНДИКАТОРНЫХ КРАСИТЕЛЕЙ В МОДЕЛЬНЫХ БЕЛОК-ЛИПИДНЫХ СИСТЕМАХ \\ В. Трусова, Г. Горбенко, У. Тарабара, Е. Вус, О. Рыжова}

Кафедра ядерной и медицинской физики, Харьковский национальный университет имени В.Н. Каразина пл. Свободы 4, Харьков, 61022, Украина

Проанализированы протолитические и термодинамические равновесия индикаторных красителей в модельных липидных и белок-липидных системах. Предложен методологический подход, позволяющий определять коэффициенты распределения протонированной и депротонированной форм красителя на основе спектрофотометрических измерений. Изучено распределение индикаторного красителя бромтимолового синего в модельные бислойные мембраны, состоящие из фосфатидилхолина и кардиолипина (9:1, моль:моль). Показано, что коэффициент распределения протонированной формы красителя в липидную фазу на 5 порядков выше, чем коэффициент распределения депротонированной формы. Этот эффект был интерпретирован в рамках представлений о различном распределении заряда в ионах красителя, препятствующем гидрофобным взаимодействиям депротонированной формы с липидами. Наблюдаемое уменьшение распределения бромтимолового синего в липидный бислой в присутствии гемоглобина было объяснено белок-индуцированными изменениями структуры и физико-химических свойств границы раздела липид-вода. В практическом аспекте, полученные результаты имеют значение для разработки заменителей крови на основе гемосом и выяснения роли гемоглобина в развитии амилоидных патологий, в частности, болезни Альцгеймера.

КЛЮЧЕВЫЕ СЛОВА: индикаторный краситель, коэффициент распределения, липосомы, гемоглобин, белок-липидные взаимодействия

The interfacial region of a lipid bilayer, containing phosphorylcholine moiety, glycerol backbone, carbonyls, upper methylene groups of acyl chains and hydrational water, plays an important role in a wide variety of membrane (C) Trusova V., Gorbenko G., Tarabara U., Vus K., Ryzhova O., 2017 
processes [1,2]. Molecular organization and physicochemical properties of the lipid-water interface can be affected by a number of agents, including proteins, ions, pharmacological compounds, etc. Several lines of evidence indicate that peptides and proteins can modify the interfacial electrostatic properties [3,4], the degree of phospholipid hydration [5-7], conformation and dynamics of phosphorylcholine group [8,9] and glycerol backbone [10,11]. One of the approaches to addressing these issues is based on analyzing the protolytic equilibria of $\mathrm{pH}$-indicator dyes whose partitioning between the aqueous and lipid phases is accompanied by the shift of the apparent ionization constant $\left(p K_{a}\right)$ due to the differences in partition coefficients of the protonated and deprotonated dye forms [12-14]. In turn, the dye partition coefficients are determined by a number of factors including the surface and dipole electrostatic potentials, interfacial hydration, the membrane molecular packing, etc. [15]. Thus, the variations of these parameters may be indicative of the changes in the structure and physicochemical properties of the lipid-water interface.

In our previous study of the lipid and hemoglobin - lipid model systems the partition coefficients of the indicator dye bromothymol blue have been derived from the $p K_{a}$ dependencies on the lipid and protein concentration [16]. However, the employed approach has a serious drawback stemming from the necessity of varying $\mathrm{pH}$ in a rather wide limits (up to $4 \mathrm{pH}$ units) to ensure reliable $p K_{a}$ estimation. This may give rise to undesirable $\mathrm{pH}$-dependent changes in the protein conformation or lipid bilayer structure. In the present study we made an attempt to overcome the above drawback.

Our goal was threefold. First, to extend the theoretical background for analyzing the protolytic and partition equilibria of the indicator dyes in the protein-lipid systems. Second, to choose most effective ways of employing the indicator dyes for monitoring the changes in the lipid bilayer properties and to work out an optimal methodology for acquisition and quantitative interpretation of the experimental data. Third, to gain further insight into the effect of hemoglobin, the main protein of red blood cells with pronounced lipid-associating ability, on the interfacial physical characteristics of the model membranes using the $\mathrm{pH}$-indicator dye bromothymol blue.

\section{EXPERIMENTAL SECTION}

Chemicals. Egg yolk phosphatidylcholine (PC) and beef heart cardiolipin (CL) were purchased from Biolek (Ukraine). Both phospholipids gave single spots by thin layer chromatography in the solvent system chloroform:methanol:acetic acid:water, 25:15:4:2, v/v). Horse hemoglobin was purchased from Reanal (Hungary) and used in the oxidized (met) form. Bromothymol blue (BTB) and butylated hydroxytoluene (BHT) were from Merck (Germany).

Preparation of liposomes. A stock suspension of unilamellar phospholipid vesicles was prepared by the method of Batzri and Korn [17]. The lipids (18 mg PC and $4 \mathrm{mg} \mathrm{CL}$ ) were codissolved with BHT in $1 \mathrm{ml}$ of ethanol. This solution was injected into $13 \mathrm{ml}$ of $5 \mathrm{mM}$ Tris-HCl buffer under continuous stirring. Ethanol was then removed by dialysis. Phospholipid concentration was determined according to the procedure of Bartlett [18]. BHT (5 mol\%) was incorporated into lipid bilayer to prevent lipid peroxidation.

Absorbance measurements. The absorbance measurements were performed with SF-46 spectrophotometer. Bromothymol blue concentration was evaluated at $\mathrm{pH}=10$ taking extinction coefficient $\varepsilon_{617}=2.25 \times 10^{4} \mathrm{M}^{-1} \mathrm{~cm}^{-1}$ for the deprotonated dye form [19]. Hemoglobin concentration was determined using the extinction coefficient $\varepsilon_{407}=5.66 \times 10^{5} \mathrm{M}^{-1} \mathrm{~cm}^{-1}$ for tetramer [20]. To ensure the protein association with lipids, the mixtures of hemoglobin with liposomes were incubated at $30^{\circ} \mathrm{C}$ for $60 \mathrm{~min}$ prior to the dye addition. To vary $\mathrm{pH}$ value, small aliquots (20 $\mu$ l) of the concentrated $\mathrm{KOH}$ solution were added to the lipid, protein and lipid-protein samples.

\section{THEORY}

Protolytic and partition equilibria of indicator dye in a suspension of lipid vesicles or protein solution

The thermodynamic acid-base equilibrium constant of indicator dye in a buffer solution is given by [14]:

$$
K_{a}^{w}=\frac{a_{H^{+}} a_{I n}}{a_{H I n}} \cong \frac{F_{H^{+}} F_{I n}^{o}}{F_{H I n}^{o}},
$$

where $a_{H^{+}}, a_{I n}, a_{H I n}$ are the activities of the protons, deprotonated (In) and protonated (HIn) dye forms, respectively; $F_{H^{+}}, F_{I n}^{o}, F_{H I n}^{o}$ are the concentrations $\left(\mathrm{mol} \mathrm{dm}^{-3}\right)$ of the corresponding species. Denoting the total dye concentration by $D_{o}$ one obtains:

$$
D_{0}=F_{I n}^{o}+F_{H I n}^{o} ; \quad F_{I n}^{o}=\frac{D_{o}}{1+\frac{F_{H^{+}}}{K_{a}^{w}}} .
$$

In a suspension of lipid vesicles the above protolytic equilibrium is shifted due to the dye distribution between aqueous (w) and lipid $(L)$ phases so that $D_{o}$ can be written as: 


$$
D_{0}=F_{I n}+F_{H I n}+B_{I n}^{L}+B_{H I n}^{L} .
$$

This process is quantitatively described in terms of partition coefficients defined as:

$$
P_{H I n}^{L}=\frac{n_{H I n}^{L} v_{w}}{n_{H I n}^{w} v_{L}}=\frac{B_{H I n}^{L} v_{w}}{F_{H I n} v_{L}} ; \quad P_{I n}^{L}=\frac{n_{I n}^{L} v_{w}}{n_{I n}^{w} v_{L}}=\frac{B_{I n}^{L} v_{w}}{F_{I n} v_{L}},
$$

where $n$ is the number of moles of different dye species in aqueous and lipid phases, $v_{w}, v_{L}$ are the volumes of these phases given by: $v_{L}=N_{A} C_{L} V_{L} ; v_{w}=v_{t}-v_{L}, N_{A}$ is the Avogadro's number, $V_{L}$ is the mean volume of lipid molecule, $v_{t}$ is the total volume of the system $\left(v_{t}=1 \mathrm{dm}^{3}\right)$. Within the commonly employed range of lipid concentrations $v_{L}$ is much less than $v_{t}$, i.e. $v_{w} \approx v_{t}$. Given that

$$
F_{H I n}^{w}=\frac{F_{I n} F_{H^{+}}}{K_{a}^{w}} ; \quad B_{I n}^{L}=\frac{F_{I n} P_{I n}^{L} v_{L}}{v_{w}} ; \quad B_{H I n}^{L}=\frac{F_{H I n} P_{H I n}^{L} v_{L}}{v_{w}}=\frac{F_{I n} F_{H^{+}} P_{H I n}^{L} v_{L}}{K_{a}^{w} v_{w}}
$$

Hence, Eq. (3) can be transformed to:

$$
D_{0}=F_{I n}+\frac{F_{I n} F_{H^{+}}}{K_{a}^{w}}+\frac{F_{I n} P_{I n}^{L} v_{L}}{v_{w}}+\frac{F_{I n} F_{H^{+}} P_{H I n}^{L} v_{L}}{K_{a}^{w} v_{w}}=F_{I n}\left(1+\frac{F_{H^{+}}}{K_{a}^{w}}+\frac{P_{I n}^{L} v_{L}}{v_{w}}+\frac{P_{H I n}^{L} F_{H^{+}} v_{L}}{K_{a}^{w} v_{w}}\right) .
$$

The process of the dye partitioning into a lipid phase can be examined through monitoring the absorbance changes of the In or HIn dye species. In the case where the absorbance measured in a buffer solution $\left(A_{o}\right)$ or liposomal suspension $\left(A_{L}\right)$ is determined only by the deprotonated dye form the following relationships hold:

$$
A_{o}=\varepsilon_{f} F_{I n}^{o} ; \quad A_{L}=\varepsilon_{f} F_{I n}+\varepsilon_{b}^{L} B_{I n}^{L},
$$

where $\varepsilon_{f}, \varepsilon_{b}^{L}$ are the extinction coefficients of the free and bound In species at a certain wavelength $\lambda_{\text {In }}$ (usually corresponding to the maximum of the absorption spectrum). By combining the Eqs. (2-7) the difference between the dye absorbances in a buffer and liposomal suspension can be written as:

$$
\begin{gathered}
\Delta A_{L}=A_{o}-A_{L}=\varepsilon_{f}\left(F_{I n}^{o}-F_{I n}\right)-\varepsilon_{b}^{L} B_{I n}^{L}, \\
\Delta A_{L}=\frac{\left(\varepsilon_{f}-\varepsilon_{b}^{L}\right) D_{o} P_{I n}^{L} \frac{v_{L}}{v_{w}}+\left(\varepsilon_{f} P_{H I n}^{L}-\varepsilon_{b}^{L} P_{I n}^{L}\right) D_{o} \frac{F_{H^{+}}}{K_{a}^{w}} \frac{v_{L}}{v_{w}}}{\left(1+\frac{F_{H^{+}}}{K_{a}^{w}}\right)\left(1+\frac{F_{H^{+}}}{K_{a}^{w}}+P_{I n}^{L} \frac{v_{L}}{v_{w}}+P_{H I n}^{L} \frac{F_{H^{+}}}{K_{a}^{w}} \frac{v_{L}}{v_{w}}\right)},
\end{gathered}
$$

here $F_{H^{+}}=10^{-p H}$. Equating the $\Delta A_{L}$ derivative to zero yields the proton concentration corresponding to a maximum $\Delta A_{L}$ value:

$$
\frac{d \Delta A_{L}}{d F_{H^{+}}}=0 ; \quad F_{H^{+}}^{\max }=K_{a}^{w} \sqrt{\frac{1+P_{\operatorname{In}}^{L} \frac{v_{L}}{v_{w}}}{1+P_{H I n}^{L} \frac{v_{L}}{v_{w}}}} .
$$

It follows that $\triangle A_{L}$ plot vs. $\mathrm{pH}$ has an extremum at $\mathrm{pH}$ value given by:

$$
p H_{\max }=p K_{a}^{w}-0.5 \lg \left(\frac{1+P_{I n}^{L} \frac{v_{L}}{v_{w}}}{1+P_{H I n}^{L} \frac{v_{L}}{v_{w}}}\right) .
$$

In analogous manner one can describe the dye distribution in a protein solution. In this case the change in the absorbance of the deprotonated dye form is a function of the partition coefficients $\left(P_{H I n}^{P}, P_{I n}^{P}\right)$; extinction coefficient of the protein-bound In form $\left(\varepsilon_{b}^{P}\right)$ and the volume of the protein phase $\left(v_{P}\right)$ : 


$$
\Delta A_{P}=\frac{\left(\varepsilon_{f}-\varepsilon_{b}^{P}\right) D_{o} P_{I n}^{P} \frac{v_{P}}{v_{w}}+\left(\varepsilon_{f} P_{H I n}^{P}-\varepsilon_{b}^{P} P_{I n}^{P}\right) D_{o} \frac{F_{H^{+}}}{K_{a}^{w}} \frac{v_{P}}{v_{w}}}{\left(1+\frac{F_{H^{+}}}{K_{a}^{w}}\right)\left(1+\frac{F_{H^{+}}}{K_{a}^{w}}+P_{I n}^{P} \frac{v_{P}}{v_{w}}+P_{H I n}^{P} \frac{F_{H^{+}}}{K_{a}^{w}} \frac{v_{P}}{v_{w}}\right)} .
$$

\section{Partition behavior of indicator dye in the protein-lipid system}

The model studies of the protein interactions with the interfacial membrane region are usually conducted with the water-soluble proteins [5]. In such protein-lipid systems the dye tends to distribute between the protein free in solution and the membrane composed of lipids and bound protein. Thus, the expression for the total dye concentration may be written as:

$$
D_{0}=F_{I n}+F_{H I n}+B_{I n}^{m}+B_{H I n}^{m}+B_{I n}^{P}+B_{H I n}^{P},
$$

where $B_{I n}^{m}, B_{H I n}^{m}$ are the concentrations of the membrane-bound dye species. By analogy with (5) one obtains:

$$
B_{I n}^{P}=\frac{F_{I n} P_{I n}^{P} v_{P}}{v_{w}} ; B_{H I n}^{P}=\frac{F_{I n} F_{H^{+}} P_{H I n}^{P} v_{P}}{K_{a}^{w} v_{w}} ; B_{I n}^{m}=\frac{F_{I n} P_{I n}^{m} v_{m}}{v_{w}} ; B_{H I n}^{m}=\frac{F_{I n} F_{H^{+}} P_{H I n}^{m} v_{m}}{K_{a}^{w} v_{w}} .
$$

Thus, Eq. (12) can be transformed to:

$$
D_{0}=F_{I n}\left(1+\frac{F_{H^{+}}}{K_{a}^{w}}+\frac{P_{I n}^{m} v_{m}}{v_{w}}+\frac{P_{H I n}^{m} F_{H^{+}} v_{m}}{K_{a}^{w} v_{w}}+\frac{P_{I n}^{P} v_{P}}{v_{w}}+\frac{P_{H I n}^{P} F_{H^{+}} v_{P}}{K_{a}^{w} v_{w}}\right),
$$

where $v_{m}$ is the membrane volume accessible to the dye. The absorbance of the deprotonated dye form is given by:

$$
A_{L P}=\varepsilon_{f} F_{I n}+\varepsilon_{b}^{m} B_{I n}^{m}+\varepsilon_{b}^{P} B_{I n}^{P},
$$

where $\varepsilon_{b}^{m}$ is the extinction coefficient of the membrane-bound In species. The difference between the dye absorbances in a buffer solution and suspension of lipid vesicles containing free and lipid-bound protein is given by:

$$
\Delta A_{L P}=A_{o}-A_{L P}=\varepsilon_{f}\left(F_{I n}^{o}-F_{I n}\right)-\varepsilon_{b}^{m} B_{I n}^{m}-\varepsilon_{b}^{P} B_{I n}^{P} .
$$

Ultimately, the combination of Eqs. (2), (13) and (16) yields:

$$
\Delta A_{L P}=D_{o} \frac{\left(\varepsilon_{f}-\varepsilon_{b}^{m}\right) P_{I n}^{m} \frac{v_{m}}{v_{w}}+\left(\varepsilon_{f} P_{H I n}^{m}-\varepsilon_{b}^{m} P_{I n}^{m}\right) \frac{F_{H^{+}}}{K_{a}^{w}} \frac{v_{m}}{v_{w}}+\left(\varepsilon_{f}-\varepsilon_{b}^{P}\right) P_{I n}^{P} \frac{v_{P}}{v_{w}}+\left(\varepsilon_{f} P_{H I n}^{P}-\varepsilon_{b}^{P} P_{I n}^{P}\right) \frac{F_{H^{+}}}{K_{a}^{w}} \frac{v_{P}}{v_{w}}}{\left(1+\frac{F_{H^{+}}}{K_{a}^{w}}\right)\left(1+\frac{F_{H^{+}}}{K_{a}^{w}}+P_{I n}^{m} \frac{v_{m}}{v_{w}}+P_{H I n}^{m} \frac{F_{H^{+}}}{K_{a}^{w}} \frac{v_{m}}{v_{w}}+P_{I n}^{P} \frac{v_{P}}{v_{w}}+P_{H I n}^{P} \frac{F_{H^{+}}}{K_{a}^{w}} \frac{v_{P}}{v_{w}}\right)}
$$

\section{RESULTS AND DISCUSSION}

Simulation of indicator dye partitioning into lipid and lipid-protein model membranes

The theory predicts that the absorbance changes resulting from the dye membrane partitioning are determined by the parameters depending on the dye microenvironment in a lipid or protein phase $\left(P_{I n}^{L, P}, P_{H I n}^{L, P}, \varepsilon_{b}^{L, P}\right)$ and the experimental variables $\left(\mathrm{pH}\right.$ and $\left.C_{L, P}\right)$. Fig. 1 shows how the variations in $P_{I n}^{L}, P_{H I n}^{L}$ and $\varepsilon_{b}^{L}$ manifest themselves in the behavior of $\Delta A_{L}(\mathrm{pH})$ dependency. It appeared that $\Delta A_{L}$ attains positive values and has a clear maximum if $P_{H I n}^{L}>$ $P_{I n}^{L}$ and $\varepsilon_{b}^{L} \leq \varepsilon_{f}$ (Fig. 1A). Note that the lipid vesicles mimicking the properties of biological membranes are usually negatively charged. This gives rise to proton accumulation near the lipid-water interface [15,21]. Thus, the assumption that $\varepsilon_{b}^{L} \leq \varepsilon_{f}$ seems reasonable because membrane binding of In form is likely to result in its conversion to HIn form whose extinction coefficient at the wavelength $\lambda_{I n}$ is less than $\varepsilon_{f}$. In the case when $P_{H I n}^{L}<P_{I n}^{L}$ the sign of $\Delta A_{L}$ at a given $\mathrm{pH}$ depends on the difference between $\varepsilon_{b}^{L}$ and $\varepsilon_{f}$ (Fig. 1B). However, this difference has a slight effect on $\Delta A_{L}$ when $P_{H I n}^{L}$ is more than 100 -fold greater than $P_{I n}^{L}$ (Fig. 1C).

As follows from Eq. (10), $\mathrm{pH}_{\max }$ value does not depend on $\varepsilon_{f}$ and $\varepsilon_{b}^{L}$. Fig. 2 plots $\mathrm{pH}_{\max }$ as a function of the 
partition coefficients. The above simulated data can be used for approximate estimation of the lower limits for $P_{H I n}^{L}$ and $P_{I n}^{L}$. For instance, if $\mathrm{pH}_{\max }$ experimentally observed for a given lipid concentration is around 8 , the range of the possible values of partition coefficients is restricted to $P_{H I n}^{L}>10^{4.6}, P_{H I n}^{L}>10^{3.5}$ (Fig. 2).
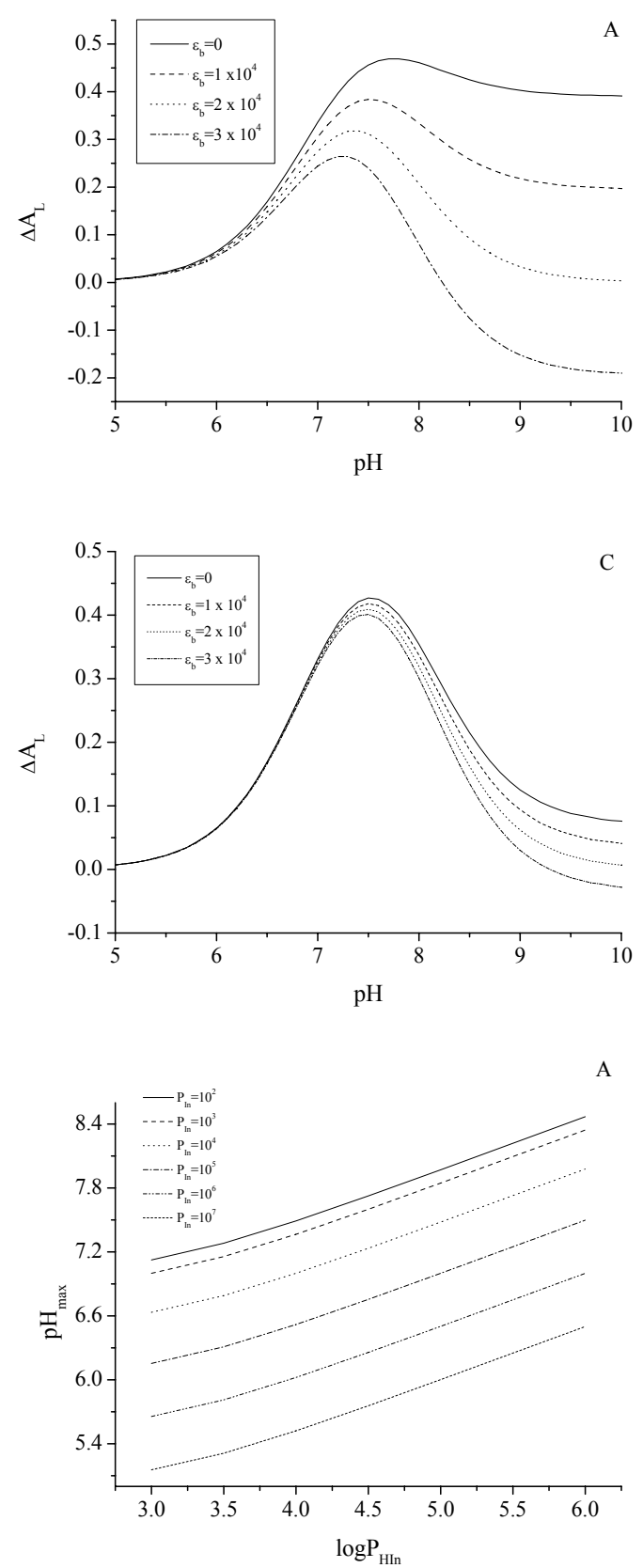

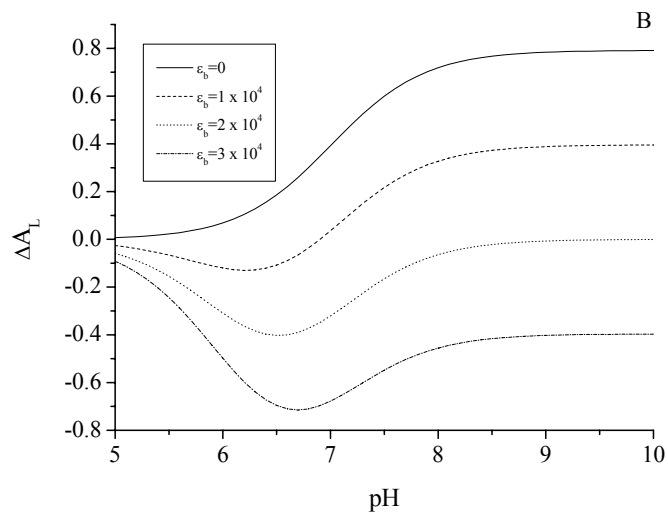

Fig. 1 Absorbance changes of the deprotonated dye form in a suspension of lipid vesicles as a function of $\mathrm{pH}$. $\Delta A_{L}$ was calculated from Eq. (8) with $D_{o}=40 \mu \mathrm{M}, C_{L}=1 \mathrm{mM}$, $p K_{a}^{w}=7, \varepsilon_{f}=2 \times 10^{4} \mathrm{M}^{-1} \mathrm{~cm}^{-1}, P_{H I n}^{L}=10^{4}, P_{I n}^{L}=10^{3}(\mathrm{~A}) ;$ $P_{H I n}^{L}=10^{4}, P_{I n}^{L}=10^{5}(\mathrm{~B}) ; P_{H I n}^{L}=10^{4}, P_{I n}^{L}=10^{2}(\mathrm{C})$. The volume of lipid phase was taken as $v_{L}=v_{P C} N_{A} C_{L}$.

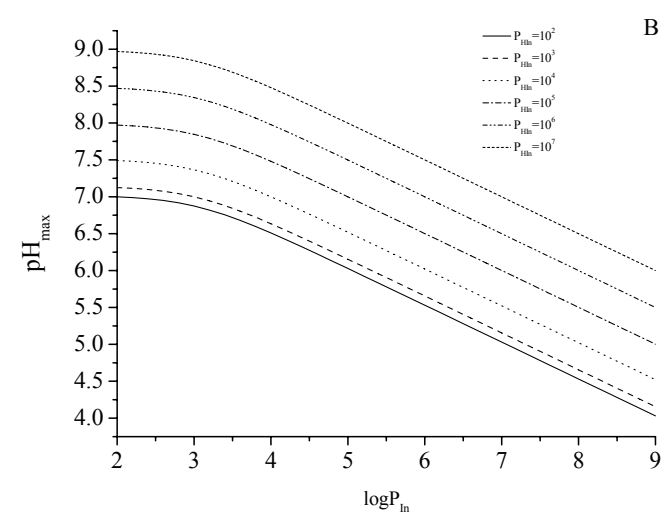

Fig. 2. $\mathrm{pH}_{\max }$ dependencies on the partition coefficients of protonated (A) and deprotonated (B) dye forms calculated from Eq. (10) using $D_{o}=40 \mu \mathrm{M}, C_{L}=1 \mathrm{mM}, p K_{a}^{w}=7$.

Next, it was of interest to ascertain what $\mathrm{pH}$ region ensures most accurate experimental estimation of $P_{H I n}^{L}$ and $P_{I n}^{L}$. Clearly, in this region $\Delta P_{H I n, I n}$ is coupled with the largest $\Delta \Delta A_{L}$, i.e. $P_{H I n}^{L}$ and $P_{I n}^{L}$ derivatives of $\Delta A_{L}$ take up their maximum or minimum at a certain $\mathrm{pH}$ (Fig. 3). In Fig. 4, pH values corresponding to the extremum values of $\Delta A_{L}$ derivatives $\left(\mathrm{pH}_{\mathrm{ext}}\right)$ are plotted vs. $P_{H I n}^{L}$ or $P_{I n}^{L}$. It appeared that within the range of partition coefficients typical for the majority of indicator dyes $\left(2 \leq \lg P_{H I n, I n} \leq 6\right)$ the difference between $\mathrm{pH}_{\text {ext }}$ and $\mathrm{pH}_{\max }$ does not exceed $2 \mathrm{pH}$ units. This implies that $\mathrm{pH}$ values falling in the range $\mathrm{pH}_{\max } \pm 1$ are preferable for the $\Delta A_{L}$ measurements. 

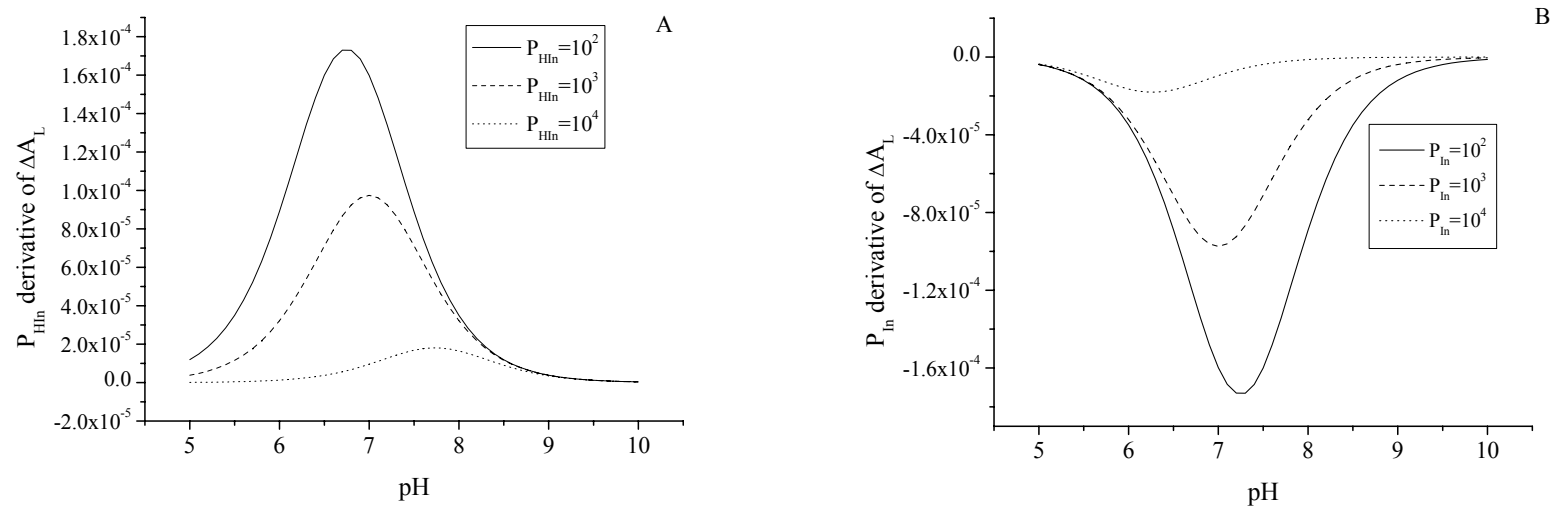

B

Fig. 3. $P_{H I n}^{L}$ and $P_{I n}^{L}$ derivatives of $\Delta A_{L}$

$$
\text { A - } P_{I n}^{L}=10^{3} ; \mathrm{B}-P_{H I n}^{L}=10^{3}, \varepsilon_{b}^{L}=2 \times 10^{4} \mathrm{M}^{-1} \mathrm{~cm}^{-1} .
$$

Importantly, $\mathrm{pH}_{\max }$ is determined not only by the dye or membrane intrinsic properties, but also depends on the lipid concentration (Eq. (10)). Hence, by varying $C_{L}$ one can shift the maximum of $\Delta A_{L}(\mathrm{pH})$ dependency towards the desirable $\mathrm{pH}$ region where the perturbations of lipid or protein structure are expected to be minimal. On the other hand, as indicated above, $\Delta A_{L}\left(C_{L}\right)$ dependencies as such or being combined with $\Delta A_{L}(\mathrm{pH})$ plots can be used for the estimation of the partition coefficients.
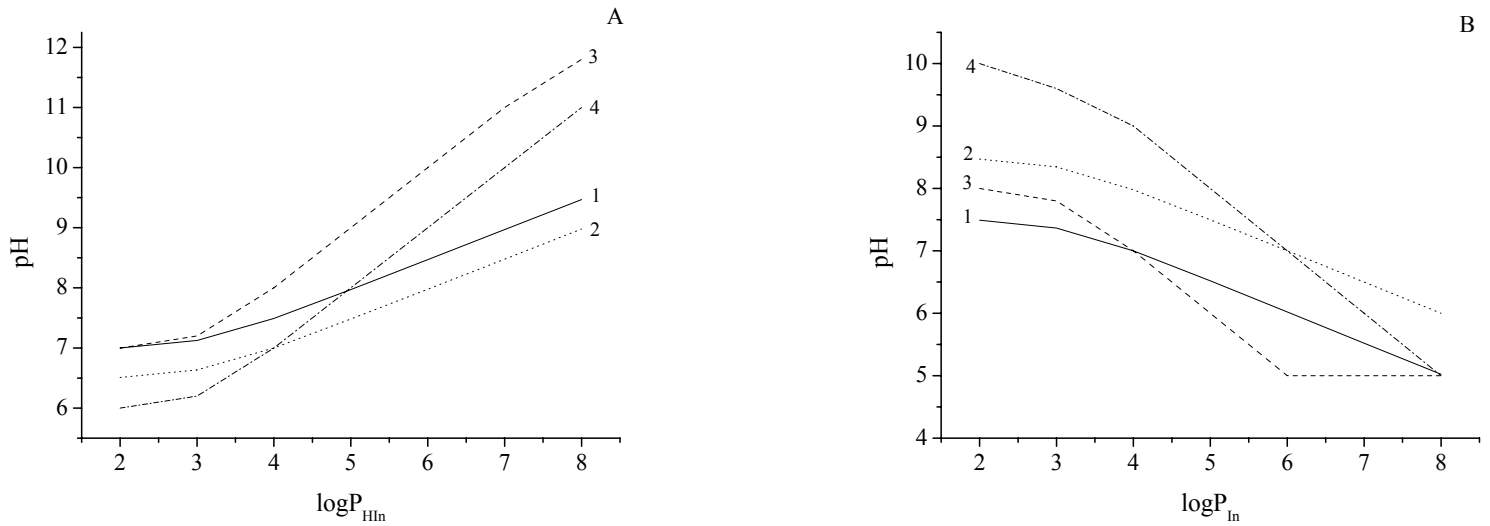

Fig. 4. $\mathrm{pH}_{\max }$ (curves 1,2) and $\mathrm{pH}_{\text {ext }}$ (curves 3,4) dependencies on partition coefficients

$$
\text { A - } P_{I n}^{L}=10^{2}(1,3), P_{I n}^{L}=10^{4}(2,4) ; \mathrm{B}-P_{H I n}^{L}=10^{4}(1,3), P_{H I n}^{L}=10^{6}(2,4) \text {. }
$$

In this case it is important to extend the range of the employed lipid concentrations to a region where $\Delta A_{L}\left(C_{L}\right)$ plots become non-linear and approach a plateau (Fig. 5).

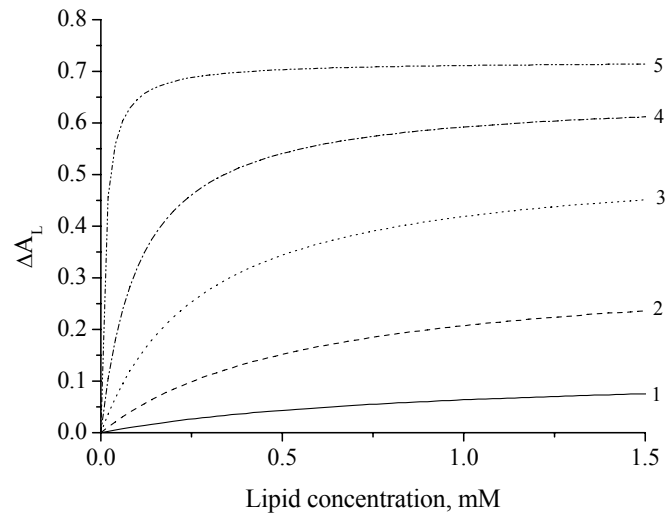

Fig. 5. Absorbance changes of the deprotonated dye form in a suspension of lipid vesicles as a function of lipid concentration

$P_{I n}^{L}=10^{3}, \log P_{H I n}^{L}: 3.5(1), 4(2), 4.5(3), 5(4), 6(5)$;

$\varepsilon_{b}^{L}=2 \times 10^{4} \mathrm{M}^{-1} \mathrm{~cm}^{-1}$.

In the protein-lipid system, $\Delta A_{L P}\left(C_{L}\right)$ curves exhibit a more complex behavior, which may be different for the various sets of parameters $\left(P_{I n}^{m}, P_{H I n}^{m}, P_{I n}^{P}, P_{H I n}^{P}, \varepsilon_{b}^{m}, \varepsilon_{b}^{P}\right)$. The main types of $\Delta A_{L P}\left(C_{L}\right)$ dependencies are shown in 
Fig. 6. In the majority of cases $\Delta A_{L P}$ increases with increasing the lipid concentration. However, when $P_{H I n}^{P}>P_{H I n}^{m}$, $P_{I n}^{P} \geq P_{I n}^{m}, \varepsilon_{b}^{m} \approx \varepsilon_{f}$, an opposite tendency is observed (Fig. 6A). Increasing the protein concentration may result in the increase (Fig. 6A,B,C) or decrease of $\Delta A_{L P}$ (Fig. 6D). Interestingly, the sign of $\Delta A_{L P}$ changes may depend on $C_{L}$ (Fig. 6E). Notably, the $\Delta A_{L P}$ sensitivity to the variations in the protein concentration can be very low at some combinations of the partition and extinction coefficients (Fig. 6F).
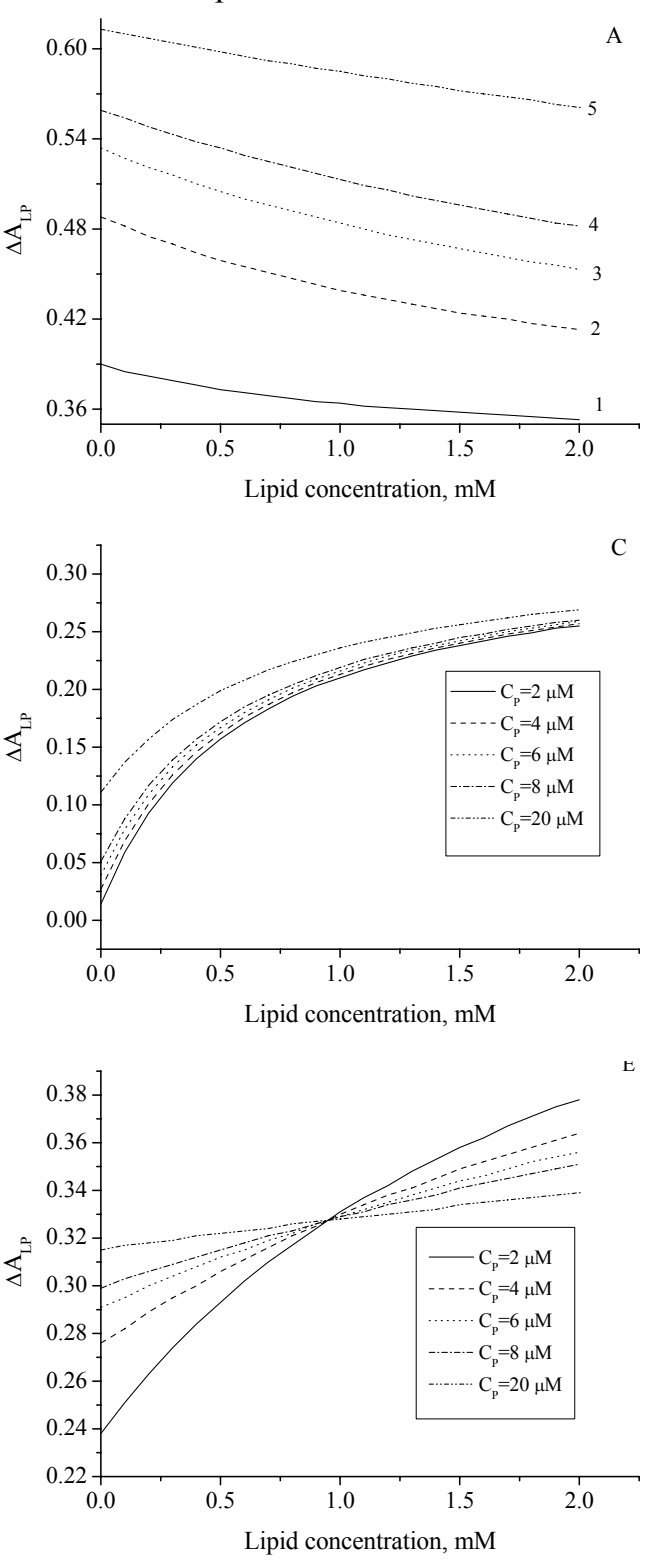
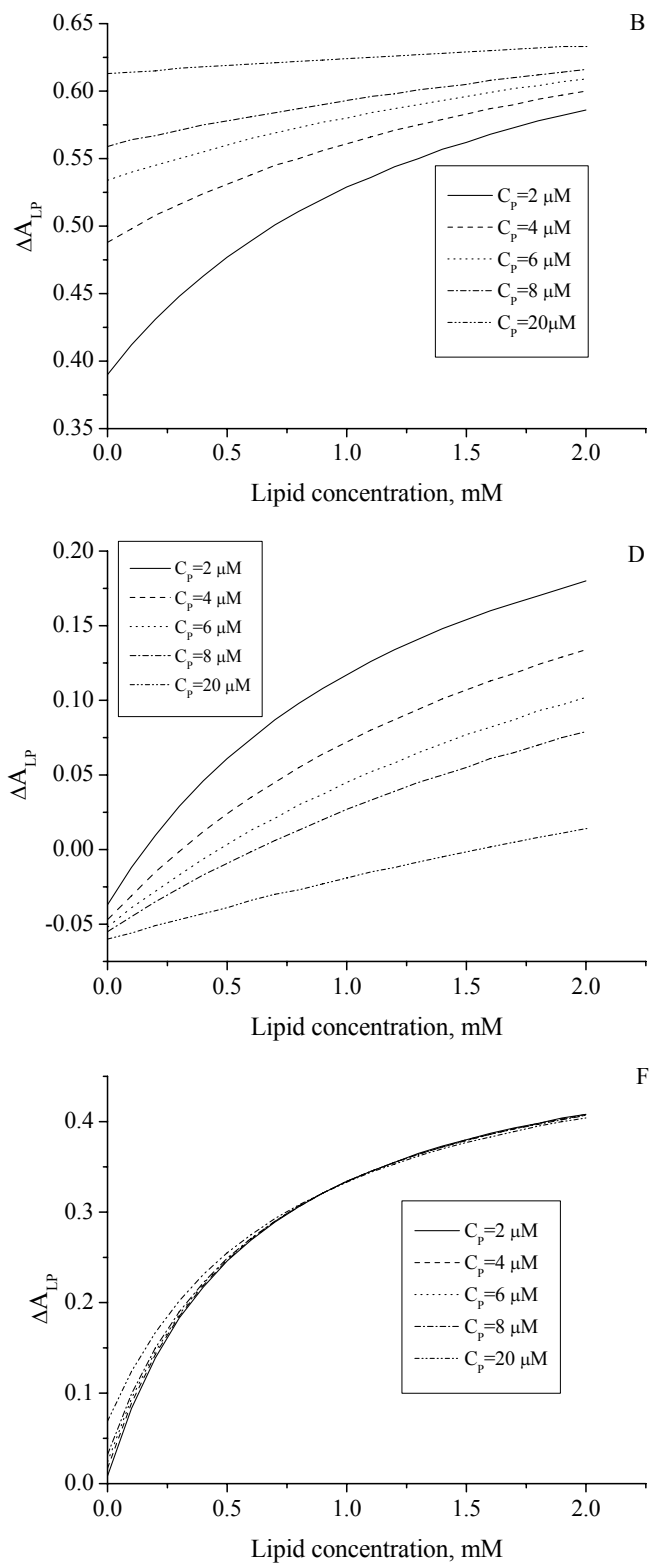

Fig. 6. Absorbance changes of the deprotonated dye form in protein-lipid systems: different types of $\Delta A_{L P}$ dependency on lipid concentration

Calculations were performed using $\mathrm{pH}=8, P_{H I n}^{L}=10^{4}, P_{I n}^{L}=10^{3}$. A - $P_{H I n}^{P}=10^{5}, P_{I n}^{P}=10^{3}, \varepsilon_{b}^{L}=\varepsilon_{b}^{P}=2 \times 10^{4} \mathrm{M}^{-1} \mathrm{~cm}^{-1}$, protein concentration, $\mu \mathrm{M}: 2$ (1), 4 (2), 6 (3), 8 (4), 20 (5); B - $P_{H I n}^{P}=10^{5}, P_{I n}^{P}=10^{3}, \varepsilon_{b}^{P}=2 \times 10^{4} \mathrm{M}^{-1} \mathrm{~cm}^{-1}, \varepsilon_{b}^{L}=0$; C - $P_{H I n}^{P}=$ $10^{3}, P_{I n}^{P}=10^{2}, \varepsilon_{b}^{L}=2 \times 10^{4} \mathrm{M}^{-1} \mathrm{~cm}^{-1}, \varepsilon_{b}^{P}=1 \times 10^{4} \mathrm{M}^{-1} \mathrm{~cm}^{-1} ; \mathrm{D}-P_{H I n}^{P}=10^{3}, P_{I n}^{P}=10^{4}, \varepsilon_{b}^{L}=\varepsilon_{b}^{P}=2 \times 10^{4} \mathrm{M}^{-1} \mathrm{~cm}^{-1} ; \mathrm{E}-$ $P_{H I n}^{P}=10^{5}, P_{I n}^{P}=10^{4}, \varepsilon_{b}^{L}=1 \times 10^{4} \mathrm{M}^{-1} \mathrm{~cm}^{-1}, \varepsilon_{b}^{P}=2 \times 10^{4} \mathrm{M}^{-1} \mathrm{~cm}^{-1} ; \mathrm{F}-P_{H I n}^{P}=10^{3}, P_{I n}^{P}=10^{2}, \varepsilon_{b}^{L}=1 \times 10^{4} \mathrm{M}^{-1} \mathrm{~cm}^{-1}$, $\varepsilon_{b}^{P}=2 \times 10^{4} \mathrm{M}^{-1} \mathrm{~cm}^{-1}$.

BTB partitioning in a suspension of lipid vesicles

The validity of the above theoretical predictions was tested in the experimental study of the system hemoglobin liposomes using the indicator dye bromothymol blue. First, the dye binding to PC/CL lipid vesicles was examined. At neutral $\mathrm{pH}$ BTB solution contains the protonated $\left(\mathrm{HIn}^{-}\right)$and deprotonated $\left(\mathrm{In}^{2-}\right)$ forms with absorption maxima at 
420 and $617 \mathrm{~nm}$, respectively [16]. The dye partitioning into a lipid bilayer is followed by significant decrease in the absorbance of $\operatorname{In}^{2-}$ form $\left(\Delta A_{617}\right)$.

Fig. 7 plots $\Delta A_{617}$ as a function of $\mathrm{pH}$ and lipid concentration. To derive the partition coefficients $P_{I n}^{L}$ and $P_{H I n}^{L}$, the experimental curves $\Delta A_{L}(\mathrm{pH})$ and $\Delta A_{L}\left(C_{L}\right)$ were fitted to Eq. (8), using $p K_{a}^{w}=6.9, D_{o}=42 \mu \mathrm{M}$, $v_{L}=\left(v_{P C} f_{P C}+v_{C L} f_{C L}\right) N_{A} C_{L}$, where $f_{P C}, f_{C L}$ are the lipid mole fractions; $v_{P C}, v_{C L}$ are the volumes of hydrated phospholipid molecules, taken as $1.58 \mathrm{~nm}^{3}$ for PC and $3 \mathrm{~nm}^{3}$ for CL [22]. The analysis of $\Delta A_{L}(\mathrm{pH})$ data sets acquired at different $C_{L}$ (Fig.7, A) and $\Delta A_{L}\left(C_{L}\right)$ data sets obtained at different $\mathrm{pH}$ (Fig.7, B) revealed that partition coefficient of the protonated dye form, $P_{H I n}^{L}$, is several orders of magnitude larger than $P_{I n}^{L}$, i.e. the extent of membrane binding of the deprotonated form is negligibly small. This finding is in agreement with the results of our previous dialysis experiments and $p K_{a}$ measurements [16]. Likewise, it appeared that there is no statistically significant difference between the $P_{H I n}^{L}$ values derived from the fitting of $\Delta A_{617}\left(C_{L}\right)$ plots obtained at $\mathrm{pH}$ varying from 6.9 to 8 . This permitted the global fit of $\Delta A_{617}\left(C_{L}, \mathrm{pH}\right)$ data set (128 experimental points, $16 C_{L}$ values, $8 \mathrm{pH}$ values), which yielded $P_{H I n}^{L}=(1.8 \pm 0.5) \times 10^{4}, P_{I n}^{L} \sim 0.1$.
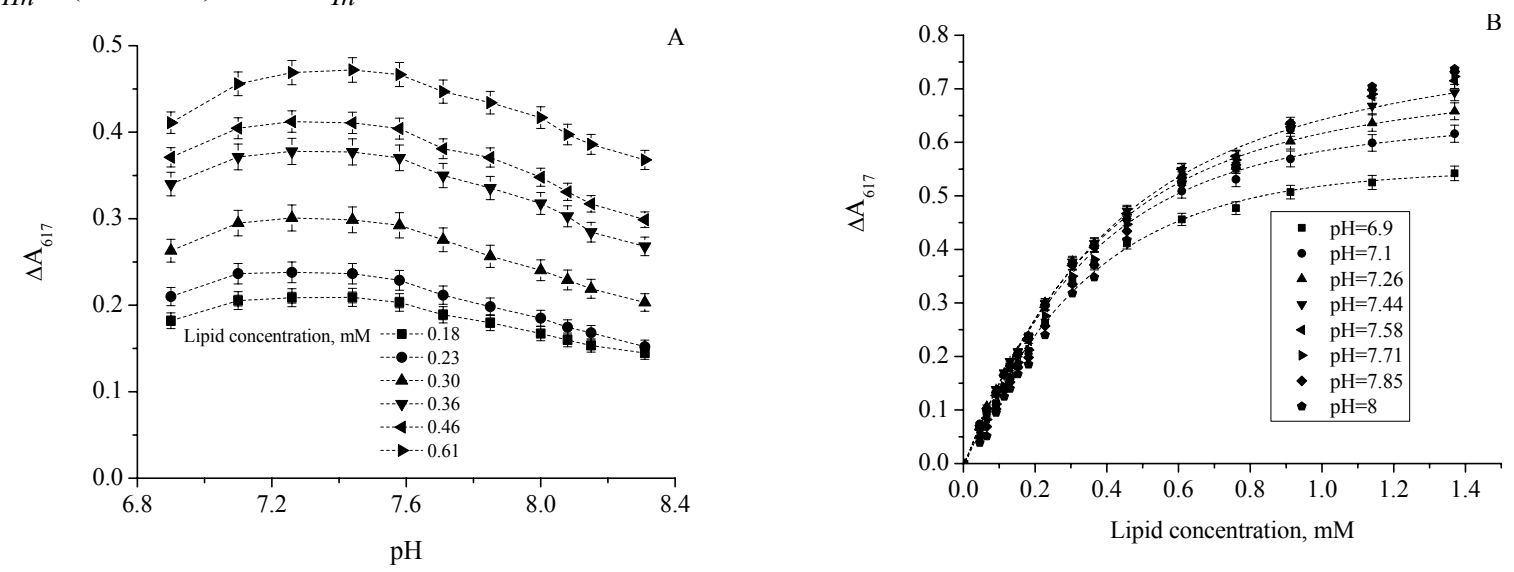

Fig. 7. Changes in the absorbance of $\mathrm{In}^{2-}$ bromothymol blue species in the suspension of PC/DPG liposomes as a function of $\mathrm{pH}(\mathrm{A})$ and lipid concentration (B)

A - lipid concentration, mM: 0.18 (1), 0.23 (2), 0.3 (3), 0.36 (4), 0.46 (5), 0.61 (6).

\section{BTB binding to hemoglobin}

The next step of the study was aimed at the characterization of BTB association with hemoglobin. Presented in Fig. 8 are the $\Delta A_{617}$ dependencies on the protein concentration.

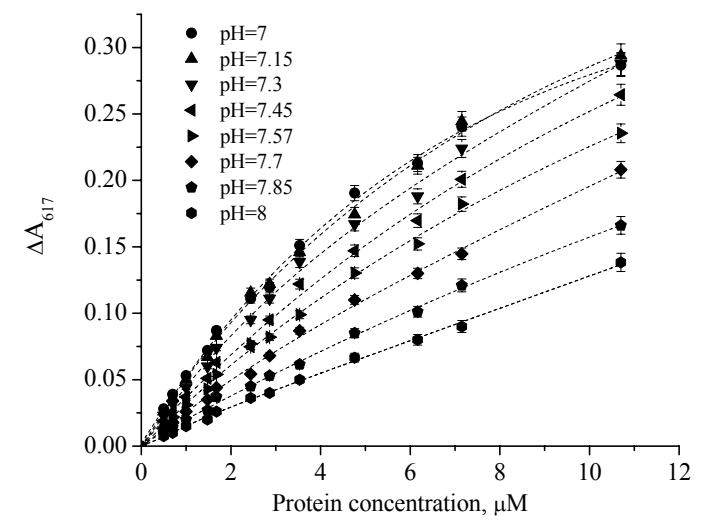

Fig. 8. The changes in the absorbance of $\operatorname{In}^{2-}$ bromothymol blue species in hemoglobin solution under conditions of varying $\mathrm{pH}$ and protein concentration.

In the fitting of these data to Eq. (11) the volume of the protein phase was determined as $v_{P}=N_{A} C_{P} V_{H b}$, where $V_{H b}$ is the volume of hydrated $\mathrm{Hb}$ molecule, taken as $120 \mathrm{~nm}^{3}$ [23]. The partition coefficient of the protonated dye form proved to be 1000-fold greater than $P_{I n}^{P}(\sim 3)$, the effect being similar to that observed for the BTB partitioning into a lipid phase. The individual analyses of $\Delta A_{617}\left(C_{P}\right)$ data corresponding to different $\mathrm{pH}$ values yielded the $P_{H I n}^{P}$ 
estimates whose variations did not exceed the experimental error within the $\mathrm{pH}$ range $7-8$. The partition coefficient of the protonated dye form refined by the global fit of all the data presented in Fig. 8 was found to be $P_{H I n}^{P}=(3.5 \pm 0.8) \times 10^{3}$.

\section{BTB partitioning in hemoglobin - PC/CL liposomal system}

At the last step of the study the BTB partitioning in the system $\mathrm{Hb}$ - liposomes was investigated under conditions of varying $\mathrm{pH}$, lipid and protein concentrations. Since the absorbance change $\Delta A_{617}$ is a function of three variables $\left(\mathrm{pH}, C_{L}, C_{P}\right.$ ), there exist several ways to recover the dye partition coefficients from the experimental data. These ways differ in the type of the data set involved in the parameter estimation procedure. In other words, one can analyze 1D, 2D or 3D data, employing different combination of the experimental variables. A question arises, what of these analyses is preferable. The main criterion for the choice of the optimal type of data set is the uniqueness of the optimizing parameter values [24]. This criterion is met in the cases of low cross-correlation between the parameters. Therefore, it seemed reasonable to evaluate the cross-correlation coefficients for the different types of data sets being fitted to Eq. (17). The two kinds of the cross-correlation coefficients between $k$-th and $l$-th parameters were estimated [25]: partial correlation coefficients

$$
r_{k, l}=\frac{-\left(\mathbf{J}^{\mathbf{T}} \mathbf{J}\right)_{k l}}{\sqrt{\left(\mathbf{J}^{\mathbf{T}} \mathbf{J}\right)_{k k} \cdot\left(\mathbf{J}^{\mathbf{T}} \mathbf{J}\right)_{l l}}},
$$

and general correlation coefficients

$$
s_{k, l}=\frac{\left[\left(\mathbf{J}^{\mathbf{T}} \mathbf{J}\right)^{-1}\right]_{k l}}{\sqrt{\left[\left(\mathbf{J}^{\mathbf{T}} \mathbf{J}\right)^{-1}\right]_{k k} \cdot\left[\left(\mathbf{J}^{\mathbf{T}} \mathbf{J}\right)^{-1}\right]_{l l}}},
$$

where

$$
J_{i, j}=\frac{\partial G\left(\alpha_{1}, \alpha_{2}, \ldots, \mathbf{X}_{i}\right)}{\partial \alpha_{j}}
$$

$G$ is the fitting function given by Eq. (17), $\mathbf{X}_{i}$ is the vector of independent variables in the $i$-th experimental point, $\alpha$ is the vector of optimizing parameters $\left\{P_{H I n}^{L}, P_{I n}^{L}, P_{H I n}^{P}, P_{I n}^{P}\right\}$, subscripts $i, j$ refer to the specific data point $\left\{\mathrm{pH}, C_{L}, C_{P}\right\}_{i}$ and specific parameter $\alpha_{j}$, respectively. Note that the parameters are thought to be highly correlated if the absolute value of the cross-correlation coefficient exceeds 0.98 [24]. The Tables 1,2 indicate how the magnitude of the parameter cross-correlation varies with increasing the number of independent experimental variables.

Table 1.

The coefficients of cross-correlation between $P_{H I n}^{L}$ and $P_{I n}^{L}$

\begin{tabular}{|c|c|c|c|}
\hline \multicolumn{2}{|c|}{ Type of dataset } & Partial correlation & General correlation \\
\hline Variables & Constants & & \\
\hline CL & $\mathrm{CP}, \mathrm{pH}$ & 0.980 & 0.989 \\
\hline $\mathrm{CL}, \mathrm{CP}$ & $\mathrm{pH}$ & 0.952 & 0.964 \\
\hline $\mathrm{CL}, \mathrm{pH}$ & $\mathrm{CP}$ & 0.973 & 0.988 \\
\hline $\mathrm{CP}, \mathrm{pH}$ & $\mathrm{CL}$ & 0.991 & 1 \\
\hline $\mathrm{CL}, \mathrm{CP}, \mathrm{pH}$ & & 0.964 & 0.953 \\
\hline
\end{tabular}

The lowest correlation between the optimizing parameters was found for the two data sets, both involving variable $C_{L}$ and $C_{P}$, with $\mathrm{pH}$ being constant in the former and variable in the latter case. The analysis of the former type data set did not reveal any noticeable $\mathrm{pH}$ dependence of the recovered partition coefficients. This implies that all experimental points $\Delta A_{617}$ (pH, $C_{L}, C_{P}$ ) can be simultaneously fitted to Eq. (17).

Table 2 .

The coefficients of cross-correlation between $P_{H I n}^{L}$ and $P_{H I n}^{P}$

\begin{tabular}{|c|c|c|c|}
\hline \multicolumn{2}{|c|}{ Type of dataset } & Partial correlation & General correlation \\
\hline Variables & Constants & & \\
\hline $\mathrm{CL}$ & $C_{P}, \mathrm{pH}$ & -0.783 & -0.890 \\
\hline $\mathrm{CL}, \mathrm{CP}$ & $\mathrm{pH}$ & -0.661 & -0.667 \\
\hline $\mathrm{CL}, \mathrm{pH}$ & $C_{P}$ & -0.758 & -0.904 \\
\hline $\mathrm{CP}, \mathrm{pH}$ & $C_{L}$ & -0.839 & 1 \\
\hline $\mathrm{CL}, \mathrm{CP}, \mathrm{pH}$ & & -0.638 & -0.656 \\
\hline
\end{tabular}

The global fit involving 144 points (6 $\mathrm{pH}$ values, $4 C_{L}$ values, $6 C_{P}$ values) gave the following partition 
coefficients $P_{H I n}^{m}=(5.4 \pm 1.3) \times 10^{3}, P_{I n}^{m} \sim 3, P_{H I n}^{P}=(3.8 \pm 0.9) \times 10^{3}, P_{I n}^{P} \sim 3$. Note that the extinction coefficients $\varepsilon_{b}^{m}$ and $\varepsilon_{b}^{P}$ were not regarded as optimizing parameters because of negligible contribution of the deprotonated dye species to the absorbance changes. Since for all types of the systems under study $P_{H I n}$ is much greater than $P_{I n}$, in the following we restricted ourselves to the analysis of the behavior of protonated dye species.

Based on the above considerations the principal features of the indicator dye partitioning in the model membrane systems and some guides for the better experimental design may be outlined as follows. (i) The change in the absorbance of a given dye form on going from a buffer solution to a suspension of lipid vesicles attains its maximum at a certain $\mathrm{pH}\left(\mathrm{pH}_{\max }\right)$. (ii) $\mathrm{The}_{\mathrm{pH}}$ value depends on the partition coefficients of the HIn and In dye species and accessible lipid concentration. (iii) The partition coefficients of the different dye forms in the lipid system can be derived in three ways involving the fit of the data sets $\Delta A_{L}\left(C_{L}\right), \Delta A_{L}(\mathrm{pH})$ or $\Delta A_{L}\left(\mathrm{pH}, C_{L}\right)$. The accuracy of fitting parameters is highest at the $\mathrm{pH}$ values close to $\mathrm{pH}_{\max }$. (iv) Reliable estimation of the dye partition coefficients in the protein-lipid systems requires simultaneous analysis of the multiple data sets acquired at varying $\mathrm{pH}$, lipid and protein concentrations.

The next point noteworthy concerns the information content of the experimental membrane studies employing the indicator dyes. Of significance in this regard is a more detailed analysis of the partition coefficients recovered for the system $\mathrm{Hb}$ - liposomes, where the dye species distribute between aqueous phase, free protein and lipid-protein model membranes. Let us assume that $\mathrm{Hb}$ does not bind to liposomes. In this case one might expect that $P_{H I n}^{m}$ would be close to $P_{H I n}^{L}$, while $P_{H I n}^{P}$ estimated for the protein-lipid system would insignificantly differ from that derived for $\mathrm{Hb}$ in the absence of liposomes. The comparison of the partition coefficients determined for the liposomes, $\mathrm{Hb}$ and $\mathrm{Hb}-$ liposomes systems indicate that $P_{H I n}^{m}$ is less than $P_{H I n}^{L}$ by a factor of ca. 3.4. Evidently, this finding cannot be rationalized in terms of the processes not pertaining to the protein-lipid interactions. Hence, the change in the extent of BTB membrane partitioning can be considered as the evidence for $\mathrm{Hb}$ binding to liposomes. However, the coefficient of BTB partitioning into the protein phase proved to be insensitive to $\mathrm{Hb}$ association with lipids because no statistically significant variations in $P_{H I n}^{P}$ value were observed while comparing the protein and protein-lipid systems. Note that the parameters $P_{H I n}^{m}$ and $P_{H I n}^{P}$ were derived putting $C_{P}$ equal to the total protein concentration. Therefore, the fitting procedure yielded $P_{H I n}^{P}$ value averaged over the free and lipid-bound $\mathrm{Hb}$ molecules. Since the experiments were performed with the protein concentrations $(0.3-3 \mu \mathrm{M})$ significantly lower than the lipid concentrations (0.1-0.8 $\mathrm{mM})$, the changes of $P_{H I n}^{P}$ could be detected only in the case where almost all protein molecules associate with lipids and undergo considerable conformational changes. Taken together, the above rationales led us to conclude that free and bound protein states are indistinguishable under the experimental conditions employed in the present study.

In the following, it seems of importance to outline the possible explanations for the decreased partitioning of the protonated BTB form into Hb-lipid model membranes. This effect is likely to originate from the protein-induced structural reorganization of the lipid bilayer. Although lipid-associating properties of $\mathrm{Hb}$ have long been investigated by a number of methods [26-29], the mechanisms underlying $\mathrm{Hb}$ influence on a bilayer structure are far from being fully understood. This seems to be a consequence of the complexity of the problem of lipid-protein interactions, which manifests itself even in the relatively simple model systems. Numerous studies indicate that Hb-bilayer interaction involves a number of closely interrelated processes. These include: (i) the formation of electrostatic and hydrophobic protein-lipid contacts [26,27]; (ii) conformational changes of $\mathrm{Hb}$ molecule that may involve protein unfolding [27], heme displacement and reorientation [27,10], dissociation of heme - globin complex [30,31], iron release from porphyrin ring [29]; (iii) modification of the lipid bilayer structure [32,33]. The nature and relative contributions of these processes are largely dependent on the bilayer composition and experimental conditions. It should also be noted that some of the above phenomena, especially those responsible for the changes in the protein conformation, may be related to $\mathrm{Hb}$ ability to induce lipid peroxidation [29,34]. In this study the oxidative processes were suppressed by the incorporation of the free radical scavenger BHT in the lipid bilayer. Thus, one can rule out lipid peroxidation as a possible reason for the $P_{H I n}$ decrease. Another possibility lies in the bilayer perturbation on the formation of proteinlipid contacts. The results presented here were obtained in the $\mathrm{pH}$ range $7.3-8$, where $\mathrm{Hb}$ bears a net negative charge (the protein isoelectric point is about 6.8 [27]), while the two phosphate groups of CL are fully ionized and PC is a zwitterion [21]. Under these conditions, the electrostatic component of $\mathrm{Hb}$ binding to liposomes is expected to be insignificant. Therefore, the observed decrease in the extent of BTB membrane partitioning can be explained by the bilayer structural changes resulted from the hydrophobic $\mathrm{Hb}$ - lipid interactions. The evidence for substantial contribution of the hydrophobic binding component to the stability of Hb-lipid complexes has been provided by a lot of studies [26,27,32]. The insertion of $\mathrm{Hb}$ into bilayer interior is likely to be followed by the marked rearrangement of lipid molecules. This may account for the reported elsewhere $\mathrm{Hb}$-induced increase in the ion permeability of PC 
liposomes [32]. However, molecular details of the bilayer structural modification still remain unknown. Early ${ }^{31} \mathrm{P}-\mathrm{NMR}$ studies are suggestive of $\mathrm{Hb}$ ability to bring about the formation of non-lamellar structures like inverted micelles or $\mathrm{H}_{\mathrm{II}}$ phase in the phosphatidylcholine/phosphatidylethanolamine model membranes [33]. Cardiolipin, used in this work as a minor bilayer component, is known to be capable of forming non-bilayer structures in the presence of $\mathrm{Ca}^{2+}$ or cytochrome $c$ [5]. To assess such a possibility for the systems similar to ours further studies are needed. It is also unclear how the formation of non-lamellar structures could affect the bilayer affinity of the hydrophobic ions, particularly indicator dyes. According to the modern theories of membrane electrostatics the partition coefficient of hydrophobic ion is given by [15]:

$$
P_{i}=\exp \left(w_{i} / k T\right)=\exp \left(\left\{z_{i} e \psi_{e l}+w_{B o r n, i}+w_{h, i}+w_{n, i}+w_{d, i}\right\} / k T\right),
$$

where $w_{i}$ is the mean force potential associated with the force between the particle $i$ and the membrane vesicle; $k$ is the Boltzmann constant; $z_{i} e$ is the charge of the $i$-th dye species; $\psi_{e l}$ is the membrane Coulomb potential; $w_{B o r n, i}$ is the free energy of charge transfer between the media with different dielectric constants; $w_{n, i}$ is the neutral energy term determined by the hydrophobic, van der Waals and steric factors; $w_{h, i}$ is the contribution controlled by the degree of membrane hydration; $w_{d}$ is the term dependent on the membrane dipole potential $\left(\psi_{D}\right)$. The dipole potential, arising from the phosphocholine and ester carbonyl dipoles of phospholipids and molecular dipoles of interfacial water, has a magnitude of several hundreds $\mathrm{mV}$, being positive inside a lipid bilayer [35]. This membrane property is thought to be responsible for the more pronounced ability of hydrophobic anions to associate with lipids and translocate across a bilayer, compared to the structurally similar cations [36].

Due to high hydrophobicity of BTB species the dye binding to lipids and proteins is driven mainly by non-ionic interactions [37]. However, the negative charge of BTB ions prevents penetration of the dye species into hydrophobic core, thus causing them to reside in the interfacial region [13]. In this context, it is noteworthy that enormous difference in the affinity of protonated and deprotonated BTB forms for the model membranes and $\mathrm{Hb}$ is assumed to stem from the nearly even charge distribution over the $\mathrm{In}^{2-}$ ions, which renders this BTB species incapable of forming the hydrophobic contacts [37]. It cannot be excluded that BTB partitioning is governed by a membrane dipole potential. In this case the reorientation of phospholipid headgroups and the changes in the degree of bilayer hydration on the formation of $\mathrm{Hb}$-lipid contacts could manifest themselves in the reduced dye binding to a membrane. A principal possibility of the protein reorienting effect on the phospholipid dipoles has been demonstrated in studying the melittinlipid interaction [38]. It was found that this amphiphilic peptide gives rise to a rotation of the $\mathrm{N}^{+}$end of phosphocholine dipole to the aqueous phase.

In conclusion, the results of the present study can be summarized as follows. Analysis of protolytic and partition equilibria of the indicator dyes in the model lipid and lipid-protein systems showed that partition coefficients of the protonated and deprotonated dye species can be derived from the absorbance changes detected at varying $\mathrm{pH}$, lipid and protein concentrations. The proposed methodological approach offers an advantage of minimizing the $\mathrm{pH}$-dependent perturbation of the protein and lipid structure and relative simplicity of recovering the dye partition coefficients. Examination of the BTB partitioning in the system Hb-liposomes revealed that the protein binding to PC/CL model membranes is followed by 3 -fold decrease in the partition coefficient of the protonated dye form. This finding can be explained by the structural reorganization of the lipid bilayer interfacial region.

A better understanding of $\mathrm{Hb}$ - lipid interactions is of great significance in practical aspect concerning the design of hemosome-based blood substitutes [29]. Furthermore, it was shown that Hb favors the oligomerization of amyloid- $\beta$ (A $\beta$ ) peptide which plays a central role in Alzheimer's disease (AD) [39]. Hb was found in the plaque and vascular amyloid deposits in $\mathrm{AD}$ brain and the linkage between $\mathrm{Hb}$ expression and $\mathrm{AD}$ pathogenesis has been hypothesized $[39,40]$. At last, it was demonstrated that $\mathrm{Hb}$ can modulate the toxic membrane effects of oligomeric and fibrillar proteins [41].

\section{ACKNOWLEDGEMENTS}

This work was supported by the grant № 0116 U000937 for Young Scientists from the Ministry of Science and Education of Ukraine.

\section{REFERENCES}

1. White S., Ladokhin A., Jayasinghe S., Hristova K. How membranes shape protein structure // J. Biol. Chem. - 2001. Vol. 276. - P. 32395-32398.

2. Mouritsen O. Self-assembly and organization of lipid - protein membranes // Current Opin. Colloid Interface Sci. - 1998. Vol. 3. - P. 78-87.

3. Denisov G., Wanaski S., Luan P., Glaser M., McLaughlin S. Binding of basic peptides to membranes produces lateral domains enriched in the acidic lipids phosphatidylserine and phosphatidylinositol 4,5-biphosphate: an electrostatic model and experimental results // Biophys. J. - 1998. - Vol. 74. - P. 731-744.

4. Ben-Tal N., Honig B., Miller C., McLaughlin S. Electrostatic binding of proteins to membranes. Theoretical predictions and experimental results with charybdotoxin and phospholipid vesicles // Biophys. J. - 1997. - Vol. 73. - P. 1717-1727.

5. Sankaram M., Marsh D. Protein-lipid interactions with peripheral membrane proteins // Protein-Lipid Interactions / Ed. by A.Watts. - Elsevier, 1993. - P. 127-162. 
6. Kleinschmidt J., Mahaney J., Thomas D., Marsh D. Interaction of bee venom melittin with zwitterionic and negatively charged phospholipid bilayers: a spin - label electron spin resonance study // Biophys. J. - 1997. - Vol. 72. - P. 767-778.

7. Dumas F., Lebrun M., Peyron P., Lopez A., Tocanne J. The transmembrane protein bacterioopsin affects the polarity of the hydrophobic core of the host lipid bilayer // Biochim. Biophys. Acta. - 1999. - Vol. 1421. - P. 295-305.

8. Roux M., Newmann Y., Hodges R. Conformational changes of phospholipid headgroups induced by a cationic integral membrane peptide as seen by deuterium magnetic resonance // Biochem. - 1989. - Vol. 28. - P. 2313-2321.

9. Dempsey C., Bitbol M., Watts A. Interaction of melittin with mixed phospholipid membranes composed of dimyristoylphosphatidylserine studied by deuterium NMR // Biochem. - 1989. - Vol. 28. - P. 6590-6595.

10. Babin Y., D'Amour J., Pigeon M., Pezolet M. A study of the structure of polymyxin B - dipalmitoylphosphatidylglycerol complexes by vibrational spectroscopy // Biochim. Biophys. Acta. - 1987. - Vol. 903. - P. 78-88.

11. Schwarz G., Beschiachvili G. Thermodynamic and kinetic studies on the association of melittin with a phospholipid bilayer // Biochim. Biophys. Acta. - 1989. - Vol. 979. - P. 82-90.

12. Moller J., Kragh-Hansen U. Indicator dyes as probes of electrostatic potential changes on macromolecular surfaces // Biochem. - 1975. - Vol. 14. - P. 2317-2323.

13. Mashimo T., Uede I. Hydrophilic region of lecithin membranes studied by bromothymol blue and effect of inhalation anesthetic, enflurane // Proc. Natl. Acad. Sci. USA. - 1979. - Vol. 76. - P. 5114-5118.

14. Gorbenko G., Mchedlov-Petrossyan N., Chernaya T. Ionic equilibria in microheterogeneous systems. Protolytic behaviour of indicator dyes in mixed phosphatidylcholine - diphosphatidylglycerol liposomes // J. Chem. Soc. Faraday Trans. - 1998. Vol. 94. - P. 2117-2125.

15. Cevc G. Membrane electrostatics // Biochim. Biophys. Acta. - 1990. - Vol. 1031. - P. 311-382.

16. Gorbenko G. Bromothymol blue as a probe for structural changes of model membranes induced by hemoglobin // Biochim. Biophys. Acta. - 1998. - Vol. 1370. - P. 107-118.

17. Batzri S., Korn E. Single bilayer liposomes prepared without sonication // Biochim. Biophys. Acta. - 1973. - Vol. 298. P. 1015-1019.

18. Bartlett G. Phosphorus assay in column chromatography // J. Biol. Chem. - 1959. - Vol. 234. - P. 466-468.

19. Antonini E., Wyman J., Moretti R., Rossi-Fanelli A. The interaction of bromothymol blue with hemoglobin and its effect on the oxygen equilibrium // Biochim. Biophys. Acta. - 1963. - Vol. 71. - P. 124-138.

20. Benesch R., Benesch E., Yung S. Equations for the spectrophotometric analysis of hemoglobin mixtures // Anal. Biochem 1973. - Vol. 55. - P. 245-248.

21. Tocanne J., Teissie J. Ionization of phospholipids and phospholipid - supported interfacial lateral diffusion of protons in membrane model systems // Biochim. Biophys. Acta. - 1990. - Vol. 1031. - P. 111-142.

22. Ivkov V.G., Berestovsky G.N. Dynamic Structure of Lipid Bilayer. - Moscow: Nauka, 1981.

23. Cantor C.R., Shimmel P.R. Biophysical Chemistry, Part 2. - San Francisco: W.H. Freeman and Company, 1980.

24. Johnson M. Parameter correlations while curve fitting // Meth. Enzymol. - 2000. - Vol. 321. - P. 424-446.

25. Zekany L., Nagypal I. Computational methods for the determination of formation constants. - New York: Plenum Press, 1985.

26. Pitcher III W., Keller S., Huestis W. Interaction of nominally soluble proteins with phospholipid monolayers at the air-water interface // Biochim. Biophys. Acta. - 2002. - Vol. 1564. - P. 107-113.

27. Szebeni J., Hauser H., Eskelson C., Watson R., Winterhalter K. Interaction of hemoglobin derivatives with liposomes. Membrane cholesterol protects against the changes of hemoglobin // Biochem. - 1988. - Vol. 27. - P. 6425-6434.

28. Shaklai N., Yguerabide J., Ranney H. Classification and localization of hemoglobin binding sites on the red blood cell membrane // Biochem. - 1977. - Vol. 16. - P. 5593-5597.

29. Szebeni J., Di Lorio E., Hauser H., Winterhalter K. Encapsulation of hemoglobin in phospholipid liposomes: characterization and stability // Biochem. - 1985. - Vol. 24. - P. 2827-2832.

30. Marva E., Hubbel R. Denaturing interaction between sickle hemoglobin and phosphatidylserine liposomes // Blood. - 1994. Vol. 83. - P. 242-249.

31. Shviro Y., Zilber I., Shaklai N. The interaction of hemoglobin with phosphatidylserine vesicles // Biochim. Biophys. Acta. 1982. - Vol. 687. - P. 63-70.

32. Bossi L., Alema S., Calissano P., Marra E. Interaction of different forms of hemoglobin with artificial lipid membranes // Biochim. Biophys. Acta. - 1975. - Vol. 375. - P. 477-482.

33. Chupin V., Ushakova I., Bondarenko S., Vasilenko I., Serebrennikova G., Evstigneeva R., Rosenberg G., Koltsova G. 31PNMR study of methemoglobin interaction with model membranes // Bioorg. Chem. - 1982. - Vol. 9. - P. 1275-1280.

34. Gutteridge J. Age pigments and free radicals: fluorescent lipid complexes formed by iron and copper-containing proteins // Biochim. Biophys. Acta. - 1985. - Vol. 834. - P. 144-148.

35. Gross E., Bedlack R., Loew L. Dual-wavelength ratiometric fluorescence measurement of the membrane dipole potential // Biophys. J. - 1994. - Vol. 67. - P. 208-216.

36. Flewelling R., Hubbel W. The membrane dipole potential in a total membrane potential model. Application to hydrophobic ion interaction with membranes // Biophys. J. - 1986. - Vol. 49. - P. 541-552.

37. Colonna R., Del'Antone P., Azzone G. Binding changes and apparent pKa shifts of bromothymol blue as tools for mitochondrial reactions // Arch. Biochem. Biophys. - 1972. - Vol. 151. - P. 295-303.

38. Beschiaschvili G., Seelig J. Melittin binding to mixed phosphatidylglycerol - phosphatidylcholine membrane // Biochem. 1990. - Vol. 29. - P. 52-58.

39. Wu C.W., Liao P.C., Yu L., Wang S.T., Chen S.T., Wu C.M., Kuo Y.M. Hemoglobin promotes AB oligomer formation and localizes in neurons and amyloid deposits // Neurobiology of Disease. - 2004. - Vol. 17. - P. 367-377.

40. Bishop G.M., Robinson S.R., Liu Q., Perry G., Atwood C.S., Smith M.A. Iron: a pathological mediator of Alzheimer disease // Dev. Neurosci. - 2002. - Vol. 24. - P. 184-187.

41. Kutsenko O.K., Trusova V.M., Gorbenko G.P., Lipovaya A.S., Slobozhanina E.I., Lukyanenko L.M., Deligeorgiev T., Vasilev A. Fluorescence Study of the Membrane Effects of Aggregated Lysozyme // J. Fluoresc. - 2013. - Vol. 23. - P. 12291237. 